\title{
Economic structure of the population of the Rasina district with the specific reference to the employment in agriculture
}

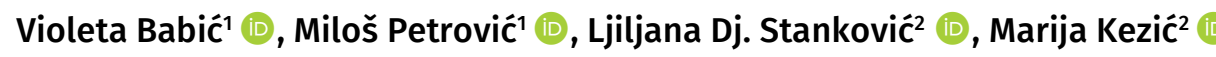 \\ ${ }^{1}$ University of Nis, Faculty of Agriculture in Krusevac, Kosančiceva 4, 37000 Kruševac \\ ${ }^{2}$ University UNION “Nikola Tesla" Belgrade, Faculty of Business Studies and Law, \\ Belgrade, Jurija Gagarina 149a, 11000 Belgrade
}

\author{
Keywords: \\ The Rasina district, \\ Population, \\ Economic structure, \\ Agriculture, \\ Employment.
}

\begin{abstract}
Demographic characteristics of the population of the Rasina district and demographic trends do not differ significantly from the characteristics and trends of the population at the level of the Republic of Serbia. The number of households and the total number of inhabitants are declining, the birth rate is also declining, mortality is rising, and the population growth is with a negative sign. Since the beginning of the 20th century, the Republic of Serbia, as well as the Rasina district, has been facing and struggling with the problem of unemployment, which exceeded $20 \%$ at the beginning of this decade. However, with the application of active employment policy measures and the arrival of foreign investors, unemployment has fallen below $10 \%$ in recent years. In the structure of employees by activities, employment in agriculture is dominant, ahead of employment in the processing industry. The problem is in the unfavorable age structure of the economically active population that performs the occupation in the status of individual farmer, which in recent years has resulted in a decrease in the number of agricultural households and registered individual farmers. The strategy of sustainable development of the city of Kruševac for the period from 2010 to 2020 recognized agriculture and the village as development potentials, so they are one of the strategic goals of sustainable development. Despite the significant financial resources allocated in this period, the depopulation and departure of young people from the villages have not been stopped.
\end{abstract}

\section{Introduction}

The population, as a factor of economic development, is important from the aspect of production as well as from the aspect of consumption of material goods, because it indicates the availability of demographic potential for economic development. Geographical position and size of this region, natural-geographical characteristics, terrain, land and climate are prerequisites for the development of agriculture and all its branches, and tradition and cultural-historical heritage, which is exceptionally large and significant, give the Rasina district a special place on the tourist map of Serbia and Europe. Therefore, this region has huge opportunities to contribute to the development of agricultural activity through employment in agriculture, and as well as to all activities with which agriculture is connected. This would contribute to the acceleration and increase of the overall economy of the region and, of course, to the national economy.

The subject of research in this paper is the analysis of the economic structure of the population of Rasina district, with special reference to employment in agriculture. The analysis of the demographic characteristics of the population of the 
Rasina district, as well as the structure of the demographic potential, especially the economic structure, is important from the aspect of considering the possibilities for the economic development of this part of Serbia. Important for this analysis are the data collected by the census, published by the Statistical Office of the Republic of Serbia, especially publications that show in detail the structure of the population by municipalities and regions in the Republic of Serbia. The analysis uses an interdisciplinary approach, historical method, methods of analysis and synthesis, statistical methods, descriptive method and comparison method.

\section{Geographical and historical characteristics of the Rasina district}

The Rasina district, which includes the area of six municipalities (Kruševac, Aleksandrovac, Trstenik, Brus, Varvarin and Ćićevac), is located in central Serbia, in the valley of the rivers Rasina, West, South and the Great Morava, and it is surrounded by mountains - Gledićke mountains, Goč, Kopaonik, Jastrebac and Željin. This district covers an area of 2,668 km², which is $3.34 \%$ of the total area of the Republic of Serbia, of which about $62 \%$ is agricultural area. A total of 241,999 inhabitants live on this area, which is $3.37 \%$ of the total population of the Republic of Serbia, in which according to the 2011 census there are 7,186,862 inhabitants. The city of Kruševac is the seat of the district and the administrative, health, educational and economic center. The district has an extremely favorable geographical position and climate, which, along with a rich cultural and historical heritage, represent a significant advantage for the development of all economic branches, especially industry, agriculture and tourism.

The Kruševac valley, which is intersected by the watercourses of the West Morava, Rasina and Pepeljuša, is extremely fertile. The average altitude of Rasina district is $300 \mathrm{~m}$, and about $35 \%$ of the total area is under forests. Fertile land in river valleys, temperate continental climate, with warm summers and variable cold and temperate winters, road network and railway lines that pass through the territory of the Rasina district and connect this region with other parts of the country are comparative advantages that this region can and must use in order to accelerate the economic development.

The Rasina district and the city of Kruševac, once the capital of Lazar's Serbia, and today the administrative center of the district, occupy an important place on the tourist map of Serbia, because they access exceptional cultural and historical sights and represent special tourist potential for the development of various types of tourism - rural, religious, recreational, wine, health, cultural, gastronomic, excursion, manifestation, congressional.

\section{Demographic characteristics of the population of the Rasina district}

The economic development of a country is conditioned by various factors, but it is certain that population growth and its dynamics represent a key factor in that development. The dual character of the population, as an input of production and the last user of production, shows that regardless of the degree of scientific and technical-technological progress, man is by far the most important factor of economic and any other prosperity (Cvetanović, 1996).

Demographic development is a complex process, which is conditioned by the natural movement of the population (birth rate, mortality and population growth), but also by the mechanical component - migration. The total number of inhabitants is one of the basic components of human potential, but in economic terms, the importance of data related to the total number of employed and unemployed, the level and degree of qualification, as well as the population density is far more significant. Quantitative and qualitative indicators

Chart 1. Movement of the number of inhabitants and the number of households in the Rasina district, by municipalities of the district, in period between 1948-2011

\begin{tabular}{|c|c|c|c|c|c|c|c|c|c|c|c|c|}
\hline \multirow{2}{*}{ Year municipalty } & \multicolumn{2}{|c|}{1948} & \multicolumn{2}{|c|}{1961} & \multicolumn{2}{|c|}{1981} & \multicolumn{2}{|c|}{1991} & \multicolumn{2}{|c|}{2002} & \multicolumn{2}{|c|}{2011} \\
\hline & Inh. & Househ. & Inh. & Househ. & Inh. & Househ. & Inh. & Househ. & Inh. & Househ. & Inh. & Househ. \\
\hline Aleksandrovac & 32,612 & 5,229 & 34,540 & 6,231 & 33,887 & 8,419 & 33,215 & 8,639 & 29,389 & 8,789 & 26,522 & 8,146 \\
\hline Brus & 23,491 & 317 & 5,606 & 225 & 22,679 & 427 & 21,331 & 692 & 18,764 & 5,840 & 16,317 & 320 \\
\hline Varvarin & 6,088 & & 26,423 & 144 & 25,779 & 6,487 & 23,821 & 328 & 20,122 & 5,998 & 17,966 & 5,544 \\
\hline Trstenik & 43,406 & & 49,107 & 11,3 & 53,570 & 43 & 54,873 & & 49,043 & 15,600 & 42,966 & 14,342 \\
\hline Kruševac & 87,853 & 19,377 & 103,190 & 25,279 & 132,972 & 36,897 & 138,111 & 39,085 & 131,368 & 40,188 & 128,752 & 40,947 \\
\hline ćićevac & 11,762 & & 12,709 & 3,075 & 12,568 & 3,445 & 11,757 & 3,317 & 10,755 & 3,332 & 9,476 & 2,971 \\
\hline The Rasina district (total) & 225,212 & 44,348 & 251,575 & 56,315 & 281,455 & 74,718 & 283,108 & 77,967 & 259,441 & 79,747 & 241,999 & 77,270 \\
\hline
\end{tabular}

Source: Comparative overview of the population in 1948, 1953, 1961, 1971, 1981, 1991, 2002 and 2011., book 20, Statistical Office of the Republic of Serbia, Belgrade, 2014 Comparative overview of the number of households between 1948-2011 and residences between 1971-2011, data by settlements, book 21, Statistical Office of the Republic of Serbia, Belgrade, 2014 
must be taken into account, as well as cultural-historical heritage and tradition (Djurić et al. 2016).

According to the 2002 census, there were 259,441 inhabitants in 296 settlements in the Rasina district, and according to the 2011 census, there were 241,999 inhabitants. There has been a noticeable the decline in the number of inhabitants in the last two decades, and the number of inhabitants in the Rasina district, in the total number and by municipalities, in the period between $1948-2011$ is shown in the previous chart. Since the beginning of the 80 's, in all municipalities of the Rasina district there is a tendency of decreasing of the number of inhabitants, except in the municipality of Kruševac, where the number of inhabitants grows until the beginning of the 90s, when the tendency of decrease begins. According to the 2011 census, the population of the Rasina district accounted for $3.36 \%$ of the total population of the Republic of Serbia, and according to the 2002 census, this indicator was at the level of $3.46 \%$, so we see a decline here as well. Almost 10 years have passed since the last census, and the new census is going to be the next year, in 2021. The number of the population of the region has continued to decline in recent years. It is estimated that in 2019, there were 224,191 inhabitants on the territory of the Rasina District, and 121,293 inhabitants in the city of Kruševac, the center of the region. (www.stat.gov.rs)

According to the 2011 census, there were 2,487,886 households in Serbia, with an average of 2.88 members per household. There were 77,270 households on the territory of the Rasina district, which is an average of 3.13 members per household. The declining trend in the number of inhabitants in the Rasina district is accompanied by a declining trend in the number of households, which is shown in Chart 1 . The Rasina district in the whole and all municipalities of the district recorded an increase in the number of households until the beginning of the 21st century, and then a decline, except for the city of Krusevac, which recorded an increase in the number of households in the entire observed period.

The average population density in the world today is about 50 inhabitants per square kilometer (inhabitants $/ \mathrm{km}^{2}$ ), while in Serbia it is much higher, because based on the 2011 census it is about 93 inhabitants $/ \mathrm{km}^{2}$. According to the 2011 census, the population density in the Rasina district is slightly below the population density level in Serbia and that is 89 inhabitants per square kilometer. The most densely populated is the town of Kruševac, which is the administrative, educational and cultural center of the region, and the least populated is the municipality of Brus, which is a hilly-mountainous area in terms of terrain. As estimated movements of population in the Rasina district show a declining trend, the population density in the district is also decreasing, so that it is estimated that in 2019 it was 84 inhabitants $/ \mathrm{km}^{2}$. (www.stat.gov.rs)

The natural movement of the population of the Republic of Serbia has shown exceptional negative aspects. The birth rate is declining, mortality is rising and consequently, the population growth is declining, so that in the last two censuses it was negative, and the declining trend continues, as shown by the data from 2018 (figure 1). Indicators of natural population movement in the territory of The Rasina district are also negative. Birth rates tend to decline, but mortality and population growth tend to increase. In relation to the Republic of Serbia, the birth rate is lower, and the mortality rate is higher, so the population growth is lower.

Chart 2 shows that the highest birth rate is in the municipality of Brus, and the lowest in the municipality of Trstenik. The highest mortality rate is recorded in Varvarin, and the lowest in Krusevac. The territory of the Rasina district, as

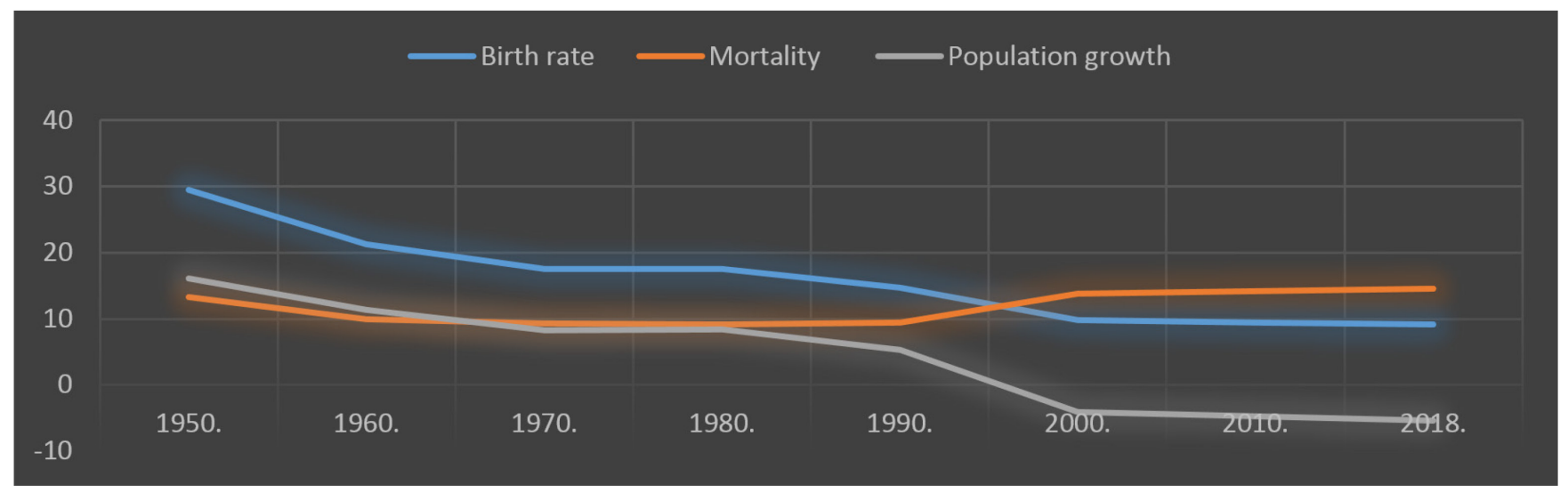

Figure 1. Natural movement of the population in the Republic of Serbia in the period between 1950-2018. Source: Municipalities and Regions in the Republic of Serbia, 2019, Statistical Office of the Republic of Serbia, Belgrade. Demographic Statistics 2016, Statistical Office of the Republic of Serbia, Belgrade 
well as the territory of the Republic of Serbia, is characterized by a negative population growth - biological depopulation. All municipalities in the region have a negative population growth and no municipality is even close to zero level. It is the lowest in the municipality of Varvarin and it is the only municipality in the region where the population growth is above -10 . The reason for such negative trends in the Rasina district are migrations from the district in the 90s of the last century, during the transition period, because this industrial region was extremely negatively affected by the process of privatizations of companies, so a large number of workers who lost their jobs left the region in search of work and better living conditions.

\section{Economic structure of the population of the Rasina district}

The development of the national economy is influenced by human capital by acting on both production and consumption. Labor affects production through employment, activity, economic activity and inactivity, while consumption is affected primarily through gender and age structure. In the Republic of Serbia, as well as in Europe, demographic aging is very noticeable, and it is predicted that the trend of demographic aging will continue in the following years. The age structure of the population is deteriorating, the supply of labor is decreasing, and the ratio between the economically active and the economically inactive population is unfavorable, which has a negative effect on labor productivity, and thus to overall economic growth. In the category of economically inactive persons, the number of pensioners is increasing, thus worsening the already unfavorable relationship between the number of pensioners and the number of employees from whose salaries pensions are financed. This additionally burdens the health care system and the state pension fund, which needs ongoing and comprehensive reforms to ensure its sustainability.

The structure of the population of the Rasina district according to economic activity, according to the 2011 census,
Chart 2. Natural movement of the population in the Rasina district in the period between 1998-2018

\begin{tabular}{ccccc}
\hline & & $\begin{array}{c}\text { Birth } \\
\text { rate }\end{array}$ & Mortality & $\begin{array}{c}\text { Population } \\
\text { growth }\end{array}$ \\
\hline The Rasina district & 1998 & 9.4 & 12.8 & -3.4 \\
The Rasina district & 2011 & 7.6 & 15.7 & -8.1 \\
The Rasina district & 2018 & 7.5 & 15.7 & -8.2 \\
Kruševac & 2018 & 7.7 & 14.8 & -7.1 \\
Aleksandrovac & 2018 & 7.9 & 16.2 & -8.3 \\
Brus & 2018 & 8 & 17.2 & -9.2 \\
Varvarin & 2018 & 7 & 18.7 & -11.7 \\
Trstenik & 2018 & 6.5 & 16.4 & -9.9 \\
Ćicevac & 2018 & 8.5 & 17.1 & -8.6 \\
\hline
\end{tabular}

Source: Demographic Statistics 2016, Statistical Office of the Republic of Serbia, Belgrade. Municipalities and Regions in the Republic of Serbia, 2012, Statistical Office of the Republic of Serbia, Belgrade. Municipalities in Serbia, 1999, Statistical Office of the Republic of Serbia, Belgrade.

is shown in the previous chart. Of the total population, $40 \%$ are active, of which $76 \%$ are employed in the Rasina district. In the total number of inactive population, pensioners are the most numerous and make up to $39 \%$, while the rest in the category of inactive population are pupils, students, housewives, children up to 15 years of age and persons with income from property.

According to the 2011 census, the labor force, which includes men, aged 15 to 64 and women, aged 15 to 59, makes up $63 \%$ of the total population of the Rasina District, or 152,528 inhabitants. The population under the age of 15 , which belongs to the pre-work contingent, makes up 13.6\% of the total population of the Rasina district, i.e. 32,872 inhabitants, while the post-work contingent (women older than 59 and men older than 64) accounts for 56,599 inhabitants, i.e. $23.4 \%$ of the total population of the Rasina district. The economically active population makes up $64 \%$ of the working contingent, i.e. 97,385 inhabitants, of which 73,998 are employed. 23,387 inhabitants of Rasina district are unemployed, and the unemployment rate is $24 \%$. If we look at the unemployment rate in the municipalities of the Rasina district, we see that the unemployment rate in 2011 was the highest in Kruševac, and the lowest in Varvarin. In the next

Chart 3. Population of the Rasina district according to economic activity, according to the 2011 census

\begin{tabular}{ccccccccc}
\hline & total & total & employees & total & $\begin{array}{c}\text { Anemployees } \\
\text { formerly worked }\end{array}$ & Looking for first job & \multicolumn{2}{c}{ Inactive population } \\
& & & & & total & pensioners \\
\hline Rasinski okrug & 241,999 & 97,385 & 73,998 & 23,387 & 19,942 & 9,445 & 144,614 & 57,238 \\
Kruševac & 128,752 & 51,299 & 35,880 & 15,419 & 9,352 & 6,067 & 77,453 & 30,367 \\
Aleksandrovac & 26,522 & 10,460 & 8,884 & 1,576 & 831 & 745 & 16,062 & 6,167 \\
Brus & 16,317 & 7,324 & 6,319 & 1,005 & 619 & 386 & 8,993 & 3,627 \\
Varvarin & 17,966 & 6,645 & 5,820 & 825 & 464 & 361 & 11,321 & 4,296 \\
Trstenik & 42,966 & 17,991 & 14,224 & 3,767 & 2,177 & 1,590 & 24,975 & 10,503 \\
Ćićevac & 9,476 & 3,666 & 2,871 & 795 & 499 & 296 & 5,810 & 2,269 \\
\hline
\end{tabular}

Source: Municipalities and Regions in the Republic of Serbia, 2019, Statistical Office of the Republic of Serbia, Belgrade 


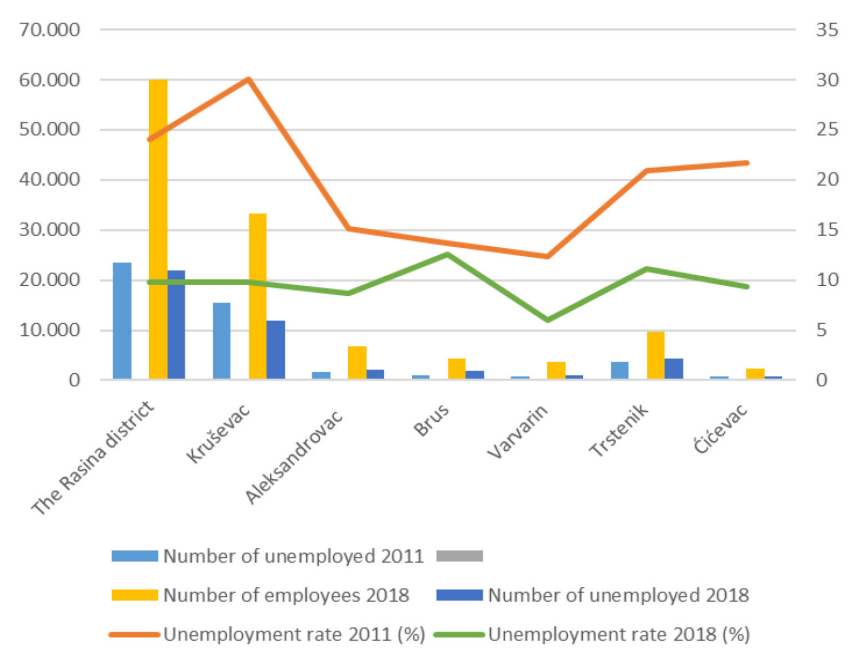

Figure 2. Employment and unemployment by municipalities of the Rasina district, 2011 and 2018. Source: Census of Population, Households and Dwellings 2011 - Population of Serbia at the Beginning of the $21^{\text {st }}$. Century, Statistical Office of the Republic of Serbia, Belgrade, 2015. Municipalities and Regions in the Republic of Serbia, 2019, Statistical Office of the Republic of Serbia, Belgrade

seven-year period, there were major changes in terms of employment in the entire Rasina district, so that in 2018, the number of unemployed people dropped significantly, and the unemployment rate fell below $10 \%$, which is shown in figure 2. In the same period, the employment rate in the Republic of Serbia reached $47.6 \%$, and the growth of employment affected the decrease in unemployment, so that the unemployment rate was $12.7 \%$. (www.stat.gov.rs)

According to the results of the census of population, households and dwellings in the Republic of Serbia, in 2011, the largest number of economically active people are engaged in the following sectors of activity: manufacturing industry (17.2\%), agriculture, forestry and fisheries (14.8\%), and wholesale and retail trade (14.7\%). It is estimated that the number of employees in agriculture, forestry and fisheries increased fom 340,186 employed inhabitants to 481,100 employed inhabitants by 2017 , which is an increase from $14.8 \%$ to $17.2 \%$. (www.stat.gov.rs)

If we look at the structure of employees by activities in the Rasina district, we see that $26 \%$ of the population is employed in agriculture, or $23 \%$ in the manufacturing industry, and these activities employ twice as many men than women. Then follow the employees in education, health care and state administration, where between 5 and 7\% of the inhabitants of the Rasina district work. In the education and health care sector, three times more women are employed than men, while in the state administration this ratio is more uniform. (Chart 4)
Chart 4. Structure of employees by activities in the Rasina district, according to the 2011 census

\begin{tabular}{lrrr}
\hline \multicolumn{1}{c}{ Type of activity } & Total & Men & Women \\
\hline Agriculture, forestry and fisheries & 19,495 & 13,639 & 5,856 \\
Mining & 148 & 129 & 19 \\
Manufacturing industry & 17,140 & 11,143 & 5,997 \\
Supply of electricity, gas, steam and air condi- & 1,017 & 844 & 173 \\
tioning & & & \\
Water supply, wastewater management and & 1,236 & 936 & 300 \\
control & 2,603 & 2,356 & 247 \\
Construction & 8,657 & 4,272 & 4,385 \\
Wholesale and retail trade; vehicle and mo- & 2,455 & 2,008 & 447 \\
torcycle repair & 1,767 & 943 & 824 \\
Traffic and storage & 727 & 469 & 258 \\
Accommodation and catering services & 891 & 294 & 597 \\
Information and communication & 71 & 35 & 36 \\
Financial and insurance activities & 1,460 & 855 & 605 \\
Real estate business & & & \\
Professional, scientific, innovative and techni- & 662 & 416 & 246 \\
cal activities & & & \\
Administrative and support service activities & 4,840 & 2,836 & 2,004 \\
Public administration and defense; compulsory & 4,334 & 1,333 & 3,001 \\
social insurance & 4,024 & 976 & 3,048 \\
Education & 832 & 504 & 328 \\
Health and social care & 1,042 & 576 & 457 \\
Art, entertainment and recreation & Other service activities & &
\end{tabular}

Source: Census of Population, Households and Dwellings in 2011 in the Republic of Serbia, Activity, Data by Municipalities and Cities, Book 15

Employment in agricultural activity in the Rasina district is over $10 \%$ higher than at the level of the Republic of Serbia. This supports the fact that the area of the Rasina district is characterized by geographical and climatic characteristics that favor the development of all agricultural branches. Compared to 2011, the total number of inhabitants in 2018 is declining, both at the level of the Republic of Serbia and at the level of the Rasina district and at the level of all municipalities in the district.

Employment in legal entities is dominant, both in the Republic of Serbia and in the Rasina district, but inequality is visible. The highest employment in legal entities is in the municipality of ćićevac, which is almost at the level of the Republic of Serbia, and the lowest is in the municipality of Varvarin and is at the level of $64 \%$.

The percentage of employment in legal entities, in the activities of agriculture, forestry and fisheries, is more uniform and close to the level of the Republic of Serbia, except in the municipalities of Trstenik and Ćićevac, where it is somewhat higher. Municipalities that have lower employment in legal entities have a higher percentage share of registered individual farmers and vice versa, so that the municipality of 
Chart 5. Registered employment in agriculture (legal entities) and registered individual farmers in\% of total employment, 2018

\begin{tabular}{|c|c|c|c|c|c|}
\hline & \multicolumn{4}{|c|}{$\begin{array}{c}\text { Employment in legal enti- } \\
\text { ties }\end{array}$} & \multirow{3}{*}{$\begin{array}{c}\text { Registered } \\
\text { individual } \\
\text { farmers } \\
\%\end{array}$} \\
\hline & \multirow[t]{2}{*}{$\begin{array}{l}\text { Popula- } \\
\text { tion }\end{array}$} & \multirow[t]{2}{*}{$\%$} & \multicolumn{2}{|c|}{$\begin{array}{c}\text { Employees in agri- } \\
\text { culture, forestry } \\
\text { and fisheries }\end{array}$} & \\
\hline & & & total & $\%$ & \\
\hline Srbija & $6,982,604$ & 96.3 & 32,679 & 1.5 & 3.7 \\
\hline The Rasina district & 224,191 & 88.5 & 787 & 1.4 & 11.5 \\
\hline Kruševac & 121,293 & 93.3 & 377 & 1.2 & 6.7 \\
\hline Aleksandrovac & 24,223 & 82.9 & 85 & 1.3 & 17.1 \\
\hline Brus & 14,814 & 81.1 & 69 & 1.8 & 17.9 \\
\hline Varvarin & 16,340 & 64.2 & 27 & 0.8 & 35.8 \\
\hline Trstenik & 38,915 & 85.6 & 192 & 2.1 & 14.4 \\
\hline ćićevac & 8,606 & 96.0 & 38 & 1.7 & 4.0 \\
\hline
\end{tabular}

Source: Municipalities and regions in the Republic of Serbia, 2019

Varvarin has the largest share of registered individual farmers of $35.8 \%$, and the municipality of ćićevac the lowest, only $4 \%$.

\subsection{Employment in agriculture - a chance for the de- velopment of the region}

As already pointed out, the area of Rasina district is characterized by geographical and climatic characteristics that favor the development of various agricultural branches, both in the field of crops and livestock production. The population of the district lives in six municipalities and in 296 settlements. The centers of the municipalities are urban settlements, and all other settlements are rural, so it is not surprising that the inhabitants of this region are engaged in agricultural activities. This means that there are 6 urban and 290 rural settlements in the region, mostly in Kruševac (100), in Brus (57), Aleksandrovac (54), Trstenik (50), Varvarin (20), and the least in Ćićevac (9), which is also the smallest municipality in the Rasina district.

According to the 2011 census of population, households and dwellings, of the total number of employees in the Rasina district, which are shown in Chart 3, and that is 73,998 inhabitants, economically active residents who work on an agricultural property are $24.78 \%$. It is 18,337 inhabitants, of which 12,765 are men and 5,572 are women. Out of that, 13,593 persons perform the occupation in the status of individual farmer, which is almost $75 \%$, which is shown in the following chart. An extremely unfavorable age structure of that population is noticeable. Namely, almost $50 \%$ of individual farmers are over 55 years old, and over $70 \%$ are over 45 years old. The young population, up to 35 years of age, is only $10 \%$. By the way, the age coefficient of the total population of the Rasina district in the period from 1971 to 2011 ranged

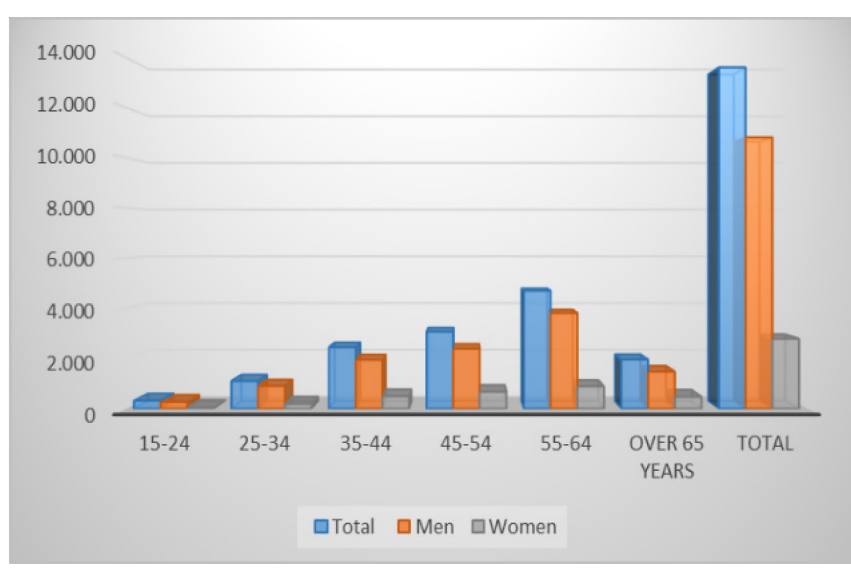

Figure 3. Economically active population of the Rasina district who performs an occupation in the status of an individual farmer, in 2011.

Source: Census of Population, Households and Dwellings 2011 in the Republic of Serbia, Economically Active. Population Performing an Occupation, Data by Statistical Office of the Republic of Serbia Districts, Belgrade, 2014, Book 19.

from 14.29 to $27.29 \%$ in 2011 . As the process of demographic aging begins when the share of the elderly reaches $12 \%$, we see that the Rasina district is in an advanced stage of the aging process (Stričević and co-workers, 2015).

Such an unfavorable age structure of the economically active population of the Rasina district, which occupies the profession as an individual farmer, resulted in a decrease in the number of agricultural farms and a decrease in the number of registered individual farmers, whose number is shown in the previous chart.

From the Chart 6, we can see that it is also on the territory of the Republic of Serbia, in the period from 2012 to 2018 the number of agricultural holdings decreased by over $10 \%$, and the number of registered individual farmers by almost $9 \%$. There is also a decline in the Rasina district, but the declining trend is a bit milder, because the number of agricultural holdings and the number of registered individual farmers decreased by about $7 \%$. In all municipalities of the Rasina district there is a decrease in these indicators, except in the municipality of Brus where there was an increase in the number of agricultural farms by $6.4 \%$ and in the municipality of Aleksandrovac where there is a slight increase in the number of registered individual farmers (only 7 more than in 2015).

The City of Kruševac and the Chamber of Commerce of the Rasina District have recognized the potential of agriculture, so the development of agriculture and villages are one of the four strategic goals in the Strategy of Sustainable Development of the City of Kruševac, for the period from 2010 to 
2020, in addition to supporting the economy and entrepreneurship, attracting investment and tourism development.

Increasing the productivity and competitiveness of agriculture can be achieved by encouraging the development of agricultural production (crop and livestock), supporting the introduction of new quality standards and supporting the processes of association of farmers and strengthening their capacity. This refers to the support of the transition from conventional to organic production, support to agricultural farms in the processes of implementation and certification of safety and quality systems, as well as increasing the yield of agricultural products by controlling diseases and pests by monitoring meteorological indicators, i.e. by building weather stations. Favorable geographical position and climate conditions, fertile agricultural land, good rural infrastructure, existence of geothermal and mineral waters, developed advisory service, favorable agro-ecological conditions and farmers' interest in applying modern achievements are the potentials that represent the basis for greater investments in agricultural production. A chance should be sought in the expansion, improvement and development of organic production, especially livestock, because the ecologically preserved natural environment at the foot of Kopaonik and Jastrebac, areas under meadows, pastures and forests, clean water and air are above average natural conditions, and the results would be multiple as well as on a demographic level, as it would slow down and to some extent stop the depopulation of mountain villages.(Katić and co-workers, 2010).

Diversification of economic activities in the countryside includes activities such as support for strengthening the capacity for processing and packaging of agricultural products, and the establishment of business incubators in villages in

Chart 6. Number of agricultural holdings and registered individual farmers in the period from 2012 to 2018

\begin{tabular}{ccccc}
\hline & \multicolumn{2}{c}{$\begin{array}{c}\text { Number of agricul- } \\
\text { tural holdings }\end{array}$} & \multicolumn{2}{c}{$\begin{array}{c}\text { Registered individual } \\
\text { farmers }\end{array}$} \\
& 2012 & 2018 & 2015 & 2017 \\
\hline Srbija & 631,552 & 565,541 & 93,320 & 85,231 \\
The Rasina district & 34,207 & 31,865 & 7,544 & 6,989 \\
Kruševac & 12,664 & 11,867 & 2,477 & 2,273 \\
Aleksandrovac & 5,543 & 5,006 & 1,161 & 1,168 \\
Brus & 4,274 & 4,547 & 776 & 736 \\
Varvarin & 3,658 & 3,222 & 1,398 & 1,250 \\
Trstenik & 6,583 & 5,775 & 1,598 & 1,447 \\
Ćićevac & 1,485 & 1,448 & 134 & 115
\end{tabular}

Source: Municipalities and regions in the Republic of Serbia, 2016. Municipalities and regions in the Republic of Serbia, 2018. Municipalities and regions in the Republic of Serbia, 2019 Statistical Office of the Republic of Serbia, Belgrade. order to identify and support activities that can generate income in rural areas.

The application of new knowledge and skills is realized through the organization of seminars and workshops in order to improve all areas of agricultural production, introducing agricultural producers to experts and new technologies through fairs and exhibitions, because by improving management production would improve and positive economic effects would increase.

City institutions have adopted a package of incentive measures, with the help of farmers' associations, and also by connecting businessmen and farmers, raising agricultural production to a higher level and expanding the market and better placement will be ensured. A chance must also be sought in the development of rural tourism and the attraction of foreign tourists. The main weakness and threat to the development of agriculture is the weakness and threats to the overall economic development, and they refer to unfavorable demographic movements and the departure of young and educated staff to larger cities or abroad, as well as insufficiently developed entrepreneurial spirit. Therefore, great efforts are being made to reduce these shortcomings to the minimum possible extent through various entrepreneurial trainings for the development of entrepreneurship of women (especially women in rural areas), youth and social entrepreneurship. The opening of the Faculty of Agriculture in Kruševac, which will, along with the professional education of young people in the field of cattle breeding (animal science), field and vegetables crops, fruit growing and viticulture, significantly contribute to this, and certainly influence not only the stay of young people in the countryside and alleviate negative demographic trends in Kruševac, and in the broader region, but also in the application of acquired knowledge in building a career in (agro) business and improving their own farms.

The City of Kruševac, the Regional Chamber of Commerce of the Rasina District, the Office for Agriculture of the City of Kruševac, the Kruševac Institute for Forage Crops, the Regional Center for Rural Development, the Regional Center for Small and Medium Enterprises, the Kruševac Tourist Organization and the Agricultural Advisory Service, which conducts counseling in mutual cooperation with agricultural producers, through various forums, workshops, visits, counseling, lectures, participate in these activities. The active participation of farmers in solving real problems gives the best results in overcoming them. (Miladinović, 2007)

Agricultural producers themselves have a significant participation in the realization of the goals, who should slowly, 


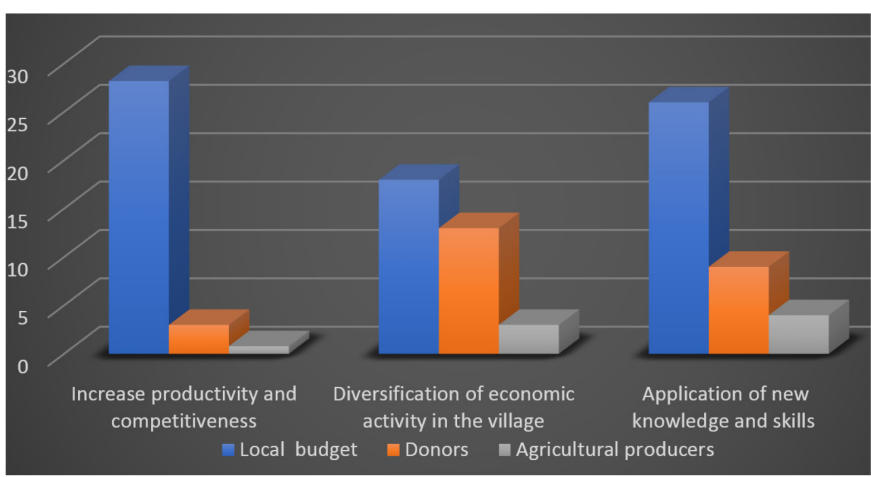

Figure 4. Financing of rural development and agriculture activities in the period 2010-2020. Source: City of Kruševac, Sustainable Development Strategy, Action Plan

with the help of the state and the city, move from a traditional - peasant household to a modern - economically sustainable agricultural farm.

In the previous ten - year period, to achieve the strategic goal of the Strategy of Sustainable Development of the City of Kruševac - Development of Agriculture and Villages, significant funds were allocated from the city budget, donors and agricultural producers, as shown in Figure 4. Most funds are provided from the city budget, and significantly less from donors and agricultural producers themselves, who are the most interested in applying new knowledge and skills, so they finance it the most. All these activities are aimed at the development of agriculture and the countryside, which is impossible to achieve without young and educated staff and their developed entrepreneurial spirit. As this ten-year period is already pointing out, and statistical data indicate a decrease in the number of agricultural farms and registered individual farmers, we cannot but conclude that serious work is being done on the realization of goals, but that there are no significant results. The age structure of the economically active population of the Rasina district, which performs the profession in the status of individual farmer, is still very unfavorable and more and more unfavorable every year, especially in the villages that are furthest from the administrative center of the district - the town of Kruševac. We must say that these villages are slowly disappearing.

We are facing a new ten-year period and time for the adoption of a new Development Strategy, in which agriculture and the countryside must again have an extremely important place, but with new activities, measures and financial incentives, both for the city and the state.

\section{CONCLUSION}

Demographic characteristics of the population of the Rasina district and demographic trends do not differ significantly from the characteristics and trends of the population at the level of the Republic of Serbia. The number of households and the total number of inhabitants are declining, the birth rate is declining, mortality is rising, and the population growth is with a negative sign. The population of Serbia is in the process of aging, and the same tendencies are in the Rasina district.

In the nineties of the last century, the Rasina district was an important industrial center, with a dominant industrial production and the industry had the most employees. Transitional changes have affected the ownership transformation and reorganization of large industrial enterprises, the number of employees has decreased significantly, and many enterprises have been completely destroyed.

Since the beginning of the 21st century, the Republic of Serbia, as well as the Rasina district, have been struggling with the problem of a high unemployment rate, which exceeded $20 \%$ at the beginning of this decade. However, with the implementation of active employment policy measures and the arrival of foreign investors, unemployment has fallen to around $10 \%$ in recent years. Small and medium enterprises are becoming the bearer of the economic development of the district, and agricultural activity is becoming dominant in the structure of employees by activities, with $26 \%$ of the employed population, in front of the processing industry, which employs $23 \%$ of the population. The Rasina district is located in a fertile Moravian valley, surrounded by mountains Kopaonik and Jastrebac, with geographical and climate conditions that affect the development of all agricultural branches, so it is not surprising that employment in agriculture in the Rasina district is higher than the employment in agriculture at the level of Serbia. In the last ten years, Rasina District and the City of Kruševac have seen agriculture and the countryside as one of the four strategic goals of sustainable development. Activities are carried out to increase the productivity and competitiveness of agriculture, diversify economic activities in the countryside and applying of the new knowledge and skills, and funds are provided from the budget of the city, donors and agricultural producers themselves. The funds are certainly not small, but as we are at the end of this period, we can say that they did not significantly contribute to the increasing of employment in agriculture and they didn't stop the departure of young people from the countryside and the return of those who 
have already left. On the contrary, the number of agricultural holdings and registered individual farmers decreased during this period. It is time for a new ten-year plan and measures that will at least mitigate these unfavorable trends. Investments must be continued and support for the activities started, in order to improve the quality and safety of the products, through support for certification and standardization. By providing additional incentives for the development of livestock production, the revitalization of mountain villages, preservation and improvement of the environment and improvement of the quality of life in rural areas can be influenced to a certain extent. Credit support is extremely important for agricultural producers, which will enable them to obtain financial resources under more favorable conditions than the market.

Violeta Babić (10 https://orcid.org/0000-0001-9536-973X Miloš Petrović (1) https://orcid.org/0000-0002-0308-8074 Ljiljana Stanković (1) https://orcid.org/0000-0001-6465-4693 Marija Kezić (10) https://orcid.org/0000-0003-2854-2648

\section{References}

Cvetanović S. (1994) Theory of Economic Development, Prosveta Nis, p. 63.

Demographic Statistics 2016, Statistical Office of the Republic of Serbia, Belgrade

Djurić K., Njegovan Z. (2016) Economics of Agriculture, Faculty of Agriculture, University of Novi Sad, p.26.

City of Kruševac, Republic of Serbia, Sustainable Development Strategy of the City of Kruševac between 20102020

Katić B., Savić M., Popović V. (2010) Organic livestock production - an unused chance of Serbia, Agricultural Economics, no. 2/2010, p. 245-255

Milovanović M. (2007) Rural Sociological approach to planning in advisory work, Agricultural Economics 2/2007, p. $287-300$

Municipalities in Serbia, 1999, Statistical office of the Republic of Serbia , Belgrade

Municipalities and regions in the Republic of Serbia, 2012, Statistical office of the Republic of Serbia, Belgrade

Municipalities and regions in the Republic of Serbia, 2016, Statistical office of the Republic of Serbia, Belgrade

Municipalities and regions in the Republic of Serbia, 2018, Statistical office of the Republic of Serbia, Belgrade

Municipalities and regions in the Republic of Serbia, 2019, Statistical Office of the Republic of Serbia , Belgrade

Census of Population, households and dwellings in 2011 in the Republic of Serbia, Activity, Data by municipalities and cities, Statistical office of the Republic of Serbia, Belgrade, book 15

Census of population, households and dwellings in 2011 in the Republic of Serbia, Economically Active Population, Data by Statistical office of the Republic of Serbia by Districts, Belgrade, 2014, Book 19

Census of Population, households and dwellings in 2011 Population of Serbia at the beginning of the 21st century, Statistical Office of the Republic of Serbia , Belgrade, 2015

Stričević Lj., Radivojević A., Golubović N., Miletić J., Milić J. (2015) Contemporary demographic changes in the territory of the Rasina district, Bulletin of the Anthropological Society of Serbia , Niš, vol. 51, p. 63-71

Comparative overview of the number of inhabitants in 1948, 1953, 1961, 1971, 1981, 1991, 2002 and 2011, book 20, Statistical Office of the Republic of Serbia, Belgrade, 2014

Comparative overview of the number of households between 1948-2011 and dwellings between 1971-2011, Data by settlements, book 21, Statistical Office of the Republic of Serbia , Belgrade, 2014

Internet sources: www.stat.gov.rs 